\title{
COMMUNITY PERCEPTION OF BUKIT RAYA VILLAGE ON COFFEE STALLS ON THE EDGE JALAN SAMARINDA - TENGGARONG
}

\author{
PERSEPSI MASYARAKAT DESA BUKIT RAYA TERHADAP \\ WARUNG KOPI DI TEPI JALAN SAMARINDA - TENGGARONG
}

\author{
Alan Chandra ${ }^{1}$, Harihanto ${ }^{2}$, Badruddin Nasir ${ }^{3}$ \\ Universitas Mulawarman, Indonesia \\ Email Correspondence: allanchandra@gmail.com
}

\begin{abstract}
:
The background of this research is the news on social media that the coffee shop on Jalan Samarinda - Tenggarong, Kilometer 10, Bukit Raya Village is considered by some members of the surrounding community to be used as a shrouded place of protection. This study aims to verify and validate the correctness of the perceptions and judgments of these community members. To achieve this goal, data has been collected from community members and leaders, as well as officials in Bukit Raya Village through interviews. The selection of community members as informants was done accidentally. Verification is also carried out through participatory observation in some of the coffee shops mentioned above. The data that had been collected were analyzed qualitatively-descriptive-interpretive. The results showed that in general the members of the Bukit Raya community were aware of these coffee shops. As far as they know, the owners and waiters of the coffee shop are not local people, but outsiders - Samarinda and it is suspected that some are from Surabaya. Some members of the Bukit Raya community think that these coffee shops are also generally used as places of disguised prostitution.
\end{abstract}

\section{Keywords: Coffee Shops, Covert Prostitution, Public Perception}

\begin{abstract}
ABSTRAK:
Hal yang melatarbelakangi penelitian ini adalah adanya berita di media sosial bahwa warung kopi yang ada di Jalan Samarinda - Tenggarong, Kilometer 10, Desa Bukit Raya dinilai oleh sebagian anggota masyarakat di sekitarnya digunakan sebagai tempat protistusi terselubung. Penelitian ini bertujuan memferifikasi dan memvalidasi kebenaran persepsi dan penilaian anggota masyarakat tersebut. Untuk mencapai tujuan ini telah dikumpulkan data dari anggota dan tokoh masyarakat, serta aparat di Desa Bukit Raya melalui wawancara. Pemilihan anggota masyarakat sebagai informan dilakukan secara kebetulan (accidental). Verifikasi juga dilakukan melalui pengamatan terlibat (observation participatory) di beberapa warung kopi yang disebut di atas. Data yang telah dikumpulkan dianalisis secara kualitatif-deskriptifinterpretatif. Hasil penelitian menunjukkan bahwa pada umumnya anggota masyarakat Desa Bukit Raya mengetahui adanya warung-warung kopi tersebut. Sepengetahuan mereka para pemilik dan pelayan warung kopi tersebut bukan orang setempat, melainkan orang luar - Samarinda dan diduga ada yang dari Surabaya. Sebagian anggota masyarakat Desa Bukit Raya menilai bahwa warung-warung kopi tersebut umumnya digunakan pula sebagai tempat prostitusi terselubung.
\end{abstract}

Kata Kunci: Persepsi Masyarakat, Prostitusi Terselubung, Warung Kopi

\begin{tabular}{l|l|l|}
\hline Article Info & & \\
\hline Received & $:$ & January 2021 \\
\hline Accepted & $:$ & January 2021 \\
\hline Published & $:$ & January 2021 \\
\hline DOI & $:$ & https://doi.org/10.30872/psd.v2i1.27 \\
\hline
\end{tabular}

\section{Copyright and License}

Authors retain copyright and grant the journal right of first publication with the work simultaneously licensed under a Creative Commons Attribution 4.0 International License that allows others to share the work with an acknowledgment of the work's authorship and initial publication in this journal. 


\section{PENDAHULUAN}

Warung kopi bukan hal yang asing lagi bagi masyarakat di Indonesia, bukan hanya sebagai tempat untuk menjual kopi, tetapi juga sebagai tempat berkumpul masyarakat untuk sekedar mengobrol dengan anggota masyarakat yang lainnya. Pada dasarnya warung kopi bukan hanya menjual kopi sebagai menu andalannya, tetapi juga menu lain seperti gorengan, indomie, dengan harga terjangkau. Warung kopi juga bukan hanya tempat berkumpulnya masyarakat kalangan bawah, tetapi dari seluruh lapisan masyarakat, banyak masyarakat yang menengah ke atas senang untuk sekedar mencicipi kopi meskipun hanya di warung kopi.

Di wilayah khususnya Provinsi Kalimantan Timur juga terdapat banyak warung-warung kopi khususnya di daerah Jl. Samarinda Tenggarong, kilometer 10, Desa Bukit Raya, Kecamatan Tenggarong Seberang. Warung kopi tersebut menjadi rest area bagi masyarakat yang berpergian ke kota Tenggarong maupun sebaliknya yaitu Kota Samarinda. Warung kopi tersebut berbeda dengan warung kopi pada umumnya, oleh masyakat sekitarnya dipersepsikan sebagai tempat protistusi terselubung. Di lokasi tersebut, terdapat sekitar puluhan warung kopi yang berjualan di Jl. Samarinda Tenggarong, Kilometer 10, jam buka warung kopi tersebut yaitu dari pagi hari hingga menjelang waktu subuh. Umumnya para pengunjung yang datang ke warung kopi tersebut ialah para supir yang melintas di jalan tersebut.

Keberadaan warung kopi yang berada di jalan poros Samarinda - Tenggarong tersebut sebenarnnya sudah mendapat teguran dari Pemerintah Kota Samarinda, dan Pemerintah Kabupaten Kutai Kartenagara, dan Ketua RT setempat. Teguran tersebut dilakukan dengan cara dengan menyebar selebaran di warung-warung kopi, teguran tersebut tidak melarang mereka untuk berjualan kopi, akan tetapi apabila berjualan kopi diiringi dengan melakukan praktik prostitusi, ini yang dilarang oleh Pemerintah. (klik Samarinda.com tahun 2016).

Diduga praktik protistusi yang berada di warung kopi Jl. Samarinda Tenggarong, diakibatkan oleh penutupan Lokalisasi Bayur yang berada di Kelurahan Sempaja Utara Kota Samarinda yang dilakukan oleh Pemerintah Kota Samarinda 1 Juni 2015. Penutupan Lokalisasi seharusnya menghentikan praktik protistusi, tetapi kenyataannya para Wanita Tuna Susila (WTS) yang berasal dari Lokalisasi Bayur berpindah tempat dengan berpura-pura berjualan kopi, sambil melakukan protistitusi secara terselubung (klik Samarinda.com tahun 2016).

Oleh karena itu keberadaan warung kopi tersebut menjadi kurang baik bagi masyarakat khususnya masyarakat Desa Bukit Raya, dan bukan hanya dijadikan tempat protistusi tetapi juga untuk menjual minuman keras. Oleh kerena itu sering terjadi perkelahian antara sesama pengunjung, tentu ini menjadikan lingkungan yang kurang baik bagi masyarakat sekitarnya. (Observasi 8 September 2018).

Masyarakat Desa Bukit Raya yang berdekatan dengan lokasi warung kopi itu merasa keberatan. Mereka pernah melakukan protes melalui Ketua RT setempat, tetapi apa yang dilakukan oleh masyarakat tersebut terkesan sia-sia karena warung kopi tersebut tetap beroprasi sampai sekarang (kaltim.prokal.com tahun 2016).

Oleh karena itu yang dirugikan di dalam masalah ini ialah masyarakat Desa Bukit Raya, dikarenakan lingkungan mereka menjadi tidak baik dikarenakan dengan adanya keberadaan warung kopi tersebut. Oleh karena itu peneliti sangat tertarik meneliti tentang "Persepi masyarakat terhadap warung kopi di tepi Jl. Samarinda Tenggarong, Kilometer 10, Desa Bukit Raya, Kecamatan Samarinda Ulu”.

\section{METODE}

Berdasarkan perumusan masalah dan tujuan penelitian yang telah diuraikan, penelitian ini merupakan penelitian kualitatif, yakni adalah penelitian yang bersifat deskriptif dan Interpretatif. Di dalam penelitian ini teori digunakan sebagai pemandu agar fokus penelitian sesuai dengan fakta di lapangan. Selain itu landasan teori juga manfaat untuk memberikan gambaran umum tentang latar penelitian dan sebagai bahan pembahasan hasil penelitian. Dalam penelitian kuantitatif, penelitian berangkat dari teori menuju data, dan berakhir pada penerimaan atau penolakan terhadap teori yang digunakan; sedangkan penelitian kualitatif bertolak dari data, memanfaatkan teori untuk menjelaskan permasalahan yang ada di warung kopi Jalan Samarinda-Tenggarong.

\subsection{Lokasi Penelitian}

1. Terdapat sejumlah warung kopi yang diduga dijadikan tempat protistusi terselubung.

2. Belum ada penelitian sebelumnya, yang meneliti tentang persepsi masyarakat terhadap warung kopi di Tepi Jl. Samarinda Tenggarong Kilometer 10, Desa Bukit Raya, Kecamatan Tenggarong Seberang.

\subsection{Fokus Penelitian}

1. Persepsi Masyarakat Desa Bukit Raya Terhadap Warung Kopi di tepi Jl. Samarinda - Tenggarong, Kilometer 10, Desa Bukit Raya, Kecamatan Tenggarong Seberang.

2. Pengetahuan masyarakat terhadap warung kopi, (b), Penilaian masyarakat terhadap warung kopi, (c), Sikap masyarakat terhadap warung kopi, (d), Harapan masyarakat terhadap warung kopi 


\subsection{Jenis Data}

1. Data primer

Data primer merupakan sumber data yang diperoleh secara langsung dari sumber asli atau pihak pertama. Data primer secara khusus dikumpulkan oleh peneliti untuk menjawab pertanyaan riset atau penelitian. Data primer dapat berupa pendapat dari masyarakat Desa Bukit Raya yang berada di sekitar warung kopi di kilometer 10 secara individu.

Hasil observasi terhadap benda - benda atau kejadian yang ada di warung kopi, au kegiatan yang ada di warung kopi. Manfaat utama dari data primer adalah bahwa unsur-unsur kebohongan tertutup terhadap sumber fenomena. Oleh karena itu, data primer lebih mencerminkan kebenaran yang dilihat. Adapun sumber data primer dalam penelitian ini adalah sebagai berikut: (1) Polsek Tenggarong Seberang, Kanit Binmas (key informan), (2) Kepala Desa Bukit Raya, Kecamatan Tenggarong Seberang, (3) Masyarakat Desa Bukit Raya yang berada di sekitar warung kopi. (Aksidental)

2. Data sekunder

Data sekunder merupakan data yang diperoleh secara tidak langsung melalui media perantara. Data sekunder pada umumnya berupa bukti data yang terkait warung kopi yang telah tertulis dari hasil pencatatan di lapangan, dan historis yang telah tersusun, baik yang dipublikasikan dan yang tidak dipublikasikan. Di dalam konteks persepsi masyarakat terhadap warung kopi, data sekunder didapat dari, artikel, media sosial, dan koran.

\subsection{Teknik Pengumpulan Data}

1. Wawancara

Teknik wawancara digunakan untuk mendapatkan tanggapan dan penilaian dari masyarakat Desa Bukit Raya terhadap warung kopi yang berada di Desa Bukit Raya, Kecamatan Tenggarong Seberang. wawancara ini dilakukan menggunakan pedoman wawancara, proses wawancara ini dilakukan secara bebas tak berstruktur maupun berstruktur. Di dalam teknik wawancara dapat menanyakan segala sesuatu yang berhubungan dengan masalah warung kopi yang diteliti kepada informan.

Pengumpulan data ini juga disebut dengan teknik komunikasi langsung. Teknik ini adalah cara mengumpulkan data yang mengharuskan seorang mengadakan kontak langsung secara lisan atau tatap muka (face to face) dengan sumber data, baik dalam situasi yang sebenarnya maupun situasi yang sengaja dibuat untuk keperluan tersebut (Hadari, 2003:103).

2. Observasi

Hadari (2003:104) (di dalam Sofianti 2016: 32) menyebutkan observasi biasa diartikan sebagai suatu pengamatan dan pencatatan secara sistematik terhadap gejala yang tampak pada obyek penelitian. Di dalam penelitian ini, penulis berkedudukan sebagai pengamat dan ikut dalam kehidupan para pedagang kopi sehingga observasi ini dapat dikategorikan kedalam observasi partisipan. Yang diobservasi dalam penelitian ini adalah, cara menjual minuman kopi, cara melayani, cara berpakaian para penjual kopi, waktu beroprasi warung kopi, dan konsumen di warung kopi.

\subsection{Teknik Analisis Data}

Sugiyono (2014:89) menyatakan bahwa analisis data adalah proses mencari dan menyusun secara sistematis data yang telah diperoleh melalui wawancara, catatan lapangan, dan dokumentasi dengan cara mengorganisasikan data ke dalam kategori, menjabarkan ke dalam unit-unit, melakukan sintesa, menyusun kedalam pola, memilih mana yang penting dan yang dipelajari dan membuat kesimpulan sehingga menjadi mudah difahami oleh diri sendiri dan orang lain. Teknik analisis data yang digunakan dalam penelitian ini adalah dengan menggunakan model analisis seperti yang telah diberikan oleh Miles dan Huberman (1984) (Sugiyono, 2014:91), sebagai berikut:

1. Reduksi Data

Data yang diperoleh di lapangan jumlahnya cukup banyak, oleh karena itu perlu secara teliti dan rinci. reduksi data berarti: merangkum, memilih hal-hal yang pokok, memfokuskan pada hal-hal yang penting, dicari tema dan polanya. Data yang telah direduksi memberikan gambaran yang jelas dan mempermudah pengumpulan data selanjutnya.

2. Penyajian Data

Setelah data direduksi, langkah berikutnya adalah penyajian data. Penyajian data dalam penelitian kualitatif dilakukan dalam bentuk uraian singkat, bagan, hubungan antar kategori, flowchart dan sebagainya. Miles dan Huberman (1984:125) menyatakan: "the most frequent form of display data forqualitative research data in the pas has been narative tex" artinya: yang paling sering digunakan untuk menyajikan data di dalam penelitian kualitatif adalah dengan teks yang bersifat naratif.

3. Verifikasi dan Penarik Kesimpulan 
Kesimpulan dalam dipenelitian ini dapat menjawab rumusan masalah yang dirumuskan sejak awal, kesimpulan dalam penelitian kualitatif yang diharapkan adalah merupakan temuan baru yang sebelumnya belum pernah ada. Temuan berupa deskripsi atau gambaran suatu obyek yang sebelumnya masih belum jelas, sehingga setelah diteliti menjadi jelas.

\section{HASIL DAN PEMBAHASAN}

\subsection{Pembahasan Mengenai Pengetahuan Masyarakat Desa Bukit Raya Terhadap Warung Kopi Samarinda - Tenggarong}

Hasil penelitian yang menunjukkan bahwa semua informan di dalam penelitian ini mengetahui keberadaan warung kopi yang beroperasi di Km 10 Jalan Samarinda - Tenggarong merupakan hal yang wajar, karena keberadaan warung kopi tersebut berada di lingkungan pemukiman masyarakat (Desa Bukit Raya). Jaraknya hanya sekitar 10 meter dari rumah warga yang terdekat.

Demikian pula pengetahuan informan yang berbeda terhadap awal kehadiran warung-warung kopi di Km 10 Jalan Samarinda - Tenggarong merupakan hal yang wajar, karena pada awalnya mereka tidak menyangka jika warung-warung kopi itu akhirnya dijadikan tempat prostitusi, sehingga bagi mereka mungkin dianggap tidak penting dan mereka tidak berusaha mengingat-ingatnya, apa lagi mencatatnya. Dari dua pendapat tentang awal kehadiran warung-warung kopi tersebut, nampaknya pendapat Kepala Desa Bukit Raya yang menyatakan bahwa warung-warung tersebut sudah ada sekitar tahun 1990-an lebih dapat dipercaya, karena sebagai Kepala Desa tentu lebih memperhatikan lingkungannya. Sedangkan pendapat ke dua yang menyatakan bahwa warungwarung kopi tersebut baru ada sekitar tahun 2000-an berasal dari informan asal Kota Samarinda yang baru pindah ke Desa Bukit Raya sekitar tahun itu. Para penjual kopi yang ada di Jl. Samarinda - Tenggarong, Desa Bukit Raya, adalah orang-orang yang berasal dari luar wilayah Desa Bukit Raya.

\subsection{Pembahasan Mengenai Penilaian Masyarakat Desa Bukit Raya Terhadap Warung Kopi, di Jalan Samarinda - Tenggarong}

Hasil penelitian menunjukkan bahwa sebagian besar informan penelitian ini (66,67\%) menilai/mempersespikan negatif warung-warung kopi, penilaian ini karena masyarakat mempersepsikan warung kopi tersebut sebagai tempat yang tidak baik, karena dijadikannya warung kopi tersebut tempat protistusi terselubung. Sama halnya yang dikatakan oleh Langvelt (1996) di dalam Harihanto (2001) yang menyatakan bahwa persepsi berhubungan dengan pendapat dan penilaian individu terhadap suatu stimulus yang dapat berakibat terhadap motivasi, kemauan dan perasaan terhadap stimulus tersebut, stimulus bisa berupa benda, isyarat, infomasi, maupun situasi dan kondisi tertentu. Di dalam konteks persepsi masyarakat Desa Bukit Raya terhadap warung kopi, warung kopi dan perilaku para penjualnya yang berpakaian seronok dan minim, serta para lelaki, khususnya para sopir yang sering mampir ke warung-warung tersebut berlaku sebagai stimulus yang dapat menimbulkan persepsi pada individu, yang melihat keberadaan warung kopi tersebut.

Hal ini juga didukung oleh hasil observasi partisipatori yang dilakukan di warung-warung kopi, menemukan bahwa para penjual kopi menggunakan pakaian yang sangat minim, dan senang merayu para pengunjung yang singgah di warung kopi milik mereka. Di dalam warung kopi juga ditemukan kamar-kamar yang pintunya tertutup kain korden, yang tampaknya sengaja disediakan oleh pemilik warung kopi untuk praktik prostitusi. Sama halnya yang dikatakan oleh Miftah (1999) di dalam Harihanto (2001) mendefinisikan bahwa persepsi sebagai proses kognitif yang bisa terjadi pada setiap orang di dalam memahami informasi tentang lingkungannya, yang dapat diperoleh melalui penglihatan, pendengaran, penghayatan, perasaan, maupun penciuman.

Penilaian masyarakat bahwa kebanyakan dari PSK di warung kopi itu adalah mereka yang terusir dari tempat Lokalisasi lain, seperti Bayur dan Solong di Kota Samarinda, bahkan ada pula yang berasal dari Lokalisasi Dolly yang berasal dari Kota Surabaya, Jawa Timur, mungkin saja benar, tapi untuk memastikan hal ini perlu dilakukan penelitian tersendiri dengan mewancarai mereka.

Hasil penelitian menunjukkan bahwa terhadap warung kopi yang ada di Desa Bukit Raya sering dilakukannya razia oleh Pemerintah Kabupaten Kutai Kartanegara, tetapi razia dan pembongkaran demi pembongkaran terkesan hanya sia-sia saja karena para penjual kopi kembali ke warung-warung mereka setelah selesai dilakukannya razia, dan para penjual kopi kembali bekerja seperti biasanya, berjualan kopi dan bekerja sebagai Pekerja Seks Komersial (PSK), mengindikasikan bahwa seolah-olah mereka tidak mempedulikan norma sosial, dan norma Agama seperti yang dikatakan Koentjoro (2004: 27) bahwa Wanita Tuna Susila (WTS)/pekerja seks komersial sebagai perempuan yang tidak menuruti aturan susila yang berlaku di masyarakat dan dianggap tidak memiliki adap dan sopan santun di dalam berhubungan seks.

Temuan yang menunjukkan bahwa salah satu informan mengatakan pemberian pelatihan kerja dirasa sangat penting untuk menyelesaikan masalah protistusi yang ada di Jl. Samarinda - Tenggarong, Desa Bukit Raya, agar para penjual kopi bisa benar-benar meninggalkan pekerjaannya sebagai Pekerja Seks Komersial 
(PSK), dan bisa bersaing di dunia kerja secara teoretik-normatif memang rasional, namun di dalam prakteknya belum tentu dapat terwujud, mengingat mereka sudah terbiasa bekerja secara mudah kecuali jika dilakukan pengawasan yang ketat dan pemberian sanksi bagi yang melanggar. Sedangkan seperti yang dinyatakan oleh Gary (1997:263) pelatihan kerja baru merupakan proses mengajarkan kerterampilan dasar yang mereka butuhkan untuk menjalankan pekerjaan mereka, dan menurut PP No. 31 tahun 2006 pelatihan kerja adalah seluruh kegiatan untuk memberi, memperoleh, meningkatkan, serta mengembangkan kompetensi kerja, produktivitas, disiplin, sikap, dan etos kerja pada tingkat keterampilan dan keahlian tertentu sesuai jenjang dan kualifikasi jabatan atau pekerjaan. Jadi belum cukup jika hanya memberikan pelatihan kerja, tetapi juga perlu diberi bantuan modal bagi mereka yang akan membuka usaha sendiri, dan penyaluran bagi mereka yang ingin bekerja.

Dari temuan-temuan di atas dapat dikatakan bahwa warung-warung kopi di Kilometer 10 Jalan Samarinda - Tenggarog dinilai negatif oleh masyarakat Desa Bukit Raya. Warung-warung kopi itu dinilai sebagai tempat prostitusi terselubung oleh para pemiliknya. Masyarakat merasa terganggu dengan keberadaan warung-warung kopi itu. Keberadaan warung-warung kpoi itu berlawanan dengan yang apa yang mereka harapkan. Kondisi ini sesuai dengan yang dinyatakan oleh Stephen (1999) bahwa penilaian negatif ialah individu memandang sebuah objek tertentu dengan pandangan yang negatif, karena tidak sesuai dengan yang ia harapkan.

Masyarakat Desa Bukit Raya menilai negatif warung-warung kopi yang ada di Kilometer 10 jalan Samarinda - Tenggarong karena mereka melihat penampilan dan cara berpakaian para penjual di warung itu dan adanya laki-laki yang sering berkumpul di warung kopi itu, serta jam buka warung kopi yang sampai larut malam/subuh sebagai situmulus yang merangsang mereka untuk memberikan respon seperti yang dinyatakan oleh Langevelt (1996) di dalam Harihanto (2001). Di dalam hal ini respon yang dimaksud berupa penolakan terhadap warung-warung kopi itu. Jika dilihat dari Teori Interaksi Simbolik, penampilan dan cara berpakaian sangat minim dari para penjual kopi, banyaknya laki-laki yang sering berkumpul, dan waktu buka warung kopi dari pagi hari hingga menjelang waktu shubuh dilihat oleh masyarakat Desa Bukit Raya sebagai simbol dari protistusi yang dilakukan di warung kopi itu.

Jika dikaitkan dengan hasil-hasil penelitian terdahulu, penilaian negatif warga Desa Bukit Raya terhadap warung-warung kopi di Kilmeter 10 jalan Samarinda - Tenggarong yang mereka yakini sebagai tempat prostitusi terselubung juga wajar mengingat penelitian yang dilakukan oleh Sofianti (2016) misalnya masyarakat di lokasi penelitian menganggap bahwa Pekerja Seks Komersial (PSK) dan protistusi ialah sesuatu yang tidak baik dan dapat berdampak buruk bagi masyarakat, salah satunya ialah menularkan penyakit. Demikian pula hasil penelitian yang dilakukan oleh Mariadi (2013) yang menunjukkan bahwa masyarakat di lokasi penelitian menyebut bahwa protistusi di sana berdampak kepada seringnya terjadi aksi kejahatan.

\subsection{Pembahasan Mengenai Sikap Masyarakat Desa Bukit Raya Terhadap Warung Kopi, di Jalan Samarinda - Tenggarong}

Hasil penelitian yang menunjukkan bahwa tidak ada penolakan dari penduduk Desa Bukit Raya terhadap keberadaan warung kopi di Jl. Samarinda - Tenggarong jika warung-warung itu memang hanya untuk menjual kopi merupakan hal yang wajar, karena warung-warung itu secara ekonomi menguntungkan Desa Bukit Raya seperti yang disampaikan oleh salah seorang penduduknya yang dijadikan sebagai informan di dalam penelitian ini. Demikian pula temuan yang menunjukkan bahwa penduduk Desa Bukit raya menolak kebaradaan warungwarung kopi itu jika warung-warung itu dialih fungsikan atau dijadikan tempat praktik protistusi terselubung adalah wajar, mengingat dapat merugikan nama Desa mereka karena prostitusi terselubung jelas merupakan suatu perbuatan yang immoral bahkan dilihat dari ajaran Agama tertentu termasuk "zina". Kata "jika" di atas menunjukkan bahwa sikap penduduk Desa Bukit Raya ini merupakan evaluasi terhadap warung-warung kopi yang ada di Jalan Samarinda - Tenggarong di wilayah Desa mereka. Hal ini sesuai dengan yang dinyatakan oleh Soekidjo (2003) bahwa salah satu komponen pembentuk sikap adalah evaluasi terhadap objek.

Hasil penelitian menunjukkan bahwa masyarakat Desa Bukit Raya menolak keberadaan warung kopi tersebut apabila digunakan sebagai tempat praktik protistusi terselubung, tetapi menerima apabila hanya digunakan sebagai tempat berjualan adalah wajar, karena mereka tinggal berdekatan dengan warung kopi itu. Demikian pula protes dan keberatan mereka yang mereka sampaikan kepada Ketua Rukun Tetangga (RT) setempat dan Kepala Desa agar ada tindakan yang lebih tegas kepada para pemilik warung kopi itu.

Jika dikaitkan dengan hasil penelitian terdahulu yang dilakukan oleh Sofianti (2016) penolakan masyarakat Desa Bukit Raya terhadap praktek prostitusi yang terjadi di dalam warung-warung kopi di Kilometer 10 Jalan Samarinda - Tenggarong itu relatif sama, karena hasil penelitian Sofianti juga menunjukkan bahwa masyarakat di lokasi penelitian menolak adanya protistusi dan para Pekeja Seks Komersial (PSK) di lingkungan mereka, dengan alasan takut kepada penyakit menular yang dapat terjadi akibat darinya. Demikian hasil penelitian Mariadi (2013) juga menunjukkan penolakan msyarakat terhadap protistusi di lokasi studi dengan alasan yang sama, ditambah lagi dengan seringnya terjadi kejahatan sebagai akibat lainnya.

Progress in Social Development: Volume 2 No 1 Januari 2021 


\subsection{Pembahasan Mengenai Harapan Masyarakat Desa Bukit Raya Terhadap Warung Kopi, di Jalan Samarinda - Tenggarong}

Hasil penelitian yang menujukkan bahwa masyarakat Desa Bukit Raya mengharapkan warung-warung kopi di Kilometer 10 Jalan Samarinda - Tenggarong itu bisa ditertibkan oleh pemerintah merupakan hal yang wajar, mengingat mereka merasa terganggu, nama desa mereka tercemar, dan mereka takut terkena penyakit menular dari praktik prostitusi di warung kopi itu yang secara teorertik memang dapat terjadi. Praktik protistusi liar sangat berdampak tidak baik bagi masyarakat sekitarnya salah satunya ialah penyakit menular yang bisa menjangkiti warga sekitar, salah satunya ialah penyakit Moluskum Kontagiosum penyakit ini bisa menular melalui hubungan sex, tetapi bisa juga menular tanpa hubungan sex seperti adanya kontak dengan yang terinfeksi seperti berjabat tangan atau pelukan, bisa juga melalui benda yang sudah terkontaminasi, Harahap (1984).

Harapan masyarakat agar pemerintah memberikan pelatihan kerja kepada para PSK di warung-warung kopi yang dimaksud dapat saja dilakukan sebagai salah satu alternatif untuk mengentaskan mereka dari kegiatan yang tidak baik itu. Namun tindakan ini belum cukup jika tidak dibarengi dengan penyaluran kerja, pemberian bantuan modal, pembinaan, dan pengawasan, serta pemberian sanksi kepada yang melanggar (yang kembali melakukan prostitusi).

\subsection{Pembahasan Mengenai Hasil Observasi Partisipatori Terhadap Warung Kopi, di Jalan Samarinda - Tenggarong}

Hasil observasi partisipatori yang bahwa penampilan dan cara berpakaian wanita penjual kopi di warung tersebut minim, hanya menggunakan tengtop, baju yang hanya menutupi dada, dan celana pendek di atas lutut selain sama dengan yang disampaikan oleh para informan juga merupakan indikasi kuat bahwa para penjual kopi itu sambil bekerja sebagai Pekerja Seks Komersial (PSK). Hasil observasi partisipatori juga menunjukkan adanya kamar di setiap warung yang pintunya ditutup kain korden juga mendukung kesimpulan ini.

Lebih-lebih hasil observasi partisipatori yang menunjukkan bahwa terdapat sebagian pelayan warung kopi itu yang menawarkan diri dan merayu para pengunjung warung jelas merupakan indikasi yang tak dapat dipungkiri bahwa warung-warung kopi di Kilometer 10 Jalan Samarinda - Tenggarong itu digunakan sebagai tempat prostitusi terselubung.

\section{KESIMPULAN}

a. Sebagian besar warga/anggota masyarakat Desa Bukit Raya, Kecamatan Tenggarong Seberang, Kabupaten Kutai Kartanegara mengetahui keberadaan warung-warung kopi di Kilometer 10 Jalan Samarinda - Tenggarong, karena warung yang terdekat dari desa hanya berjarak sekitar 10 meter.

b. Sebagian besar warga/anggota masyarakat Desa Bukit Raya, Kecamatan Tenggarong Seberang, Kabupaten Kutai Kartanegara menyatakan bahwa pemilik warung-warung kopi yang terletak di Kilometer 10 Jalan Samarinda -Tenggarong itu berasal dari luar Desa Bukit Raya, termasuk di antaranya (terutama para pekerja wanitanya) berasal dari lokalisasi resmi yang sebelumnya ditutup oleh pemerintah.

c. Menurut warga/anggota masyarakat Desa Bukit Raya, warung kopi di Kilometer 10, Jalan Samarinda - Tenggarong pertama kali muncul sekitar tahun 1990-an, dan menjadi banyak sekitar tahun 2000-an, serta mencapai puncaknya setelah ada penutupan lokalisasi pelacuran/PSK resmi beberapa tahun lalu yang dimulai dari penutupan lokalisasi Dolly di Surabaya oleh Walikota Risma Harini.

d. Melalui sejumlah simbol yang terlihat di warung-warung kopi yang terletak di Kilometer 10 Jalan Samarinda - Tenggarong Desa Bukit Raya itu, sebagian besar warga/anggota masyarakat Desa Bukit Raya menilai warung-warung kopi itu digunakan pula sebagai tempat prostitusi terselubung. Penilaian ini juga sama dengan hasil observasi partisipatori yang menemukan sejumlah indikasi kearah itu.

e. Karena dijadikan tempat prostitusi terselubung, warga/anggota masyarakat Desa Bukit Raya (termasuk warga yang sebelumnya tidak mengetahuinya) menolak warung-warung kopi yang berada di Kilometer 10, Jalan Samarinda - Tenggarong tersebut jika memang dijadikan tempat prostitusi.

f. Warga/anggota masyarakat Desa Bukit Raya berharap agar pemerintah menertibkan warung-warung kopi di Kilometer 10, Jalan Samarinda - Tenggarong itu sampai tuntas. Penanganan yang dilakukan oleh aparat/ pemerintah daerah selama ini hanya bersifat insidental dan sopradis, sehingga tidak menyelesaikan masalah, warung-warung kopi itu beroperasi kembali dengan kegiatan yang sama, yakni sebagai tempat prostitusi terselubung. 


\section{DAFTAR PUSTAKA}

Fidagta Khoironi, 2009. Expresi Keberagaman Komunitas Warung Kopi. (Analisis Profil Komunitas Warung Kopi "Blandongan" di Yogyakarta).

Gary Dessler, 1997 “Manajemen Sumber Daya Manusia”. PT Prenhallindo Jakarta

Harihanto, 2001. Persepsi, sikap, dan perilaku masyarakat terhadap air sungai kasus Program Kali Bersih di Kaligarang Jawa. Disertasi tidak diterbitkan. Bogor: Program Pascasarjana, Institut Pertanian Bogor

Hadari Nawawi, (2003) Metode Penelitian Bidang Sosial, Gajah Mada University Press, Yogyakarta.

Koentjoro, Ph.D. 2004. On The Spot: Tutur Sang Pelacur. Yogyakarta: Tinta.

Langevelt, M. J., 1996. General of Psychology. Harper and Row Publisher, New York

Marwali, Harahap. Penyakit Menular Seksual. Jakarta: PT. Gramedia

Milles, M.B. and Huberman, M.A. 1984. Qualitative Data Analysis. London: Sage Publication.

Notoatmodjo, Soekidjo, 2003, Pengembangan Sumber Daya Manusia, Jakarta: PT. Rineka Cipta

Robins, Stephen P.1999. Prilaku Organisasi. Jakarta: Erlangga.

Sugiyono. 2014. Metode Penelitian Kuantitatif, Kualitatif, dan Kombinasi (Mixed Methods). Bandung: Alfabeta.

Sarwono. S.W, 1983. Psikologi Remaja. Jakarta: Raja Grafindo Persada.

\section{Dokumen}

PP No. 31 tahun 2006 pelatihan kerja

\section{Sumber Internet}

Elvita Sofianti,2016. Persepsi Masyarakat Terhadap Mantan PSK (Pekerja Seks Komersial) yang Telah Berkeluarga (Studi di Kampung Rawa Laut, Kelurahan Panjang Selatan Kota Bandar Lampung). (digilid.unila.ac.id) (diakses tanggal 11 september 2018)

Faradina, Triska, 2007. Gambaran Persepsi Supir Bajaj Pangkalan Blok M Plaza terhadap Keselamatan Berkendara di Jalan Raya tahun 2007, [skripsi]. Program S1 K3 Fakultas Kesehatan Masyarakat Universitas Indonesia. Depok. (lib.ui.ac.id) (diakses tanggal 12 september 2018)

Lika Puspita, 2014. Interaksi Simbolik Sales Promotion Girl. (Suatu Fenomenologi Interaksi Simbolik pada Sales Promotion Girl Rokok Djarum di Kota Bengkulu). (repository.unib.ac.id) (diakses tanggal 11 september 2018)

Mariadi, 2013. Persepsi Masyarakat Tentang Protistusi Liar di Kelurahan Sempaja Utara Samarinda (neliti.com) (diakses tanggal 11 september 2018)

Prasilika, T. (2007). Studi Persepsi Resiko Keselamatan Berkendara serta Hubungannya denga Konsep Locus of Control pada Mahasiswa Kesehatan Masyarakat yang Mengendarai Motor. Unpublished Manuscript. Depok: Universitas Indonesia. (repository.unhas.ac.id) (diakses tanggal 10 september 2018) 